\title{
Post-Divorce Custody of Children According to Positive and Islamic Laws
}

\author{
Abd. Munim*) \\ *) Master of Law Faculty of Law, Univeristas Islam Sultan Agung
}

\begin{abstract}
.
The purpose of this study is to reveal and describe a more comprehensive understanding of post-divorce custody of children according to positive law and Islamic law. The research used in this research is a research in the category of literature (library research), while the approach method used in this research is the normative approach method, namely an approach based on the Koran and the Prophet's sunnah, including the interpretation of the verses. in the Koran, as well as a juridical approach, namely an approach based on legislation or disputes such as the compilation of Islamic law and jurisprudence. This research is descriptiveanalytic, namely research that aims to develop data then analyzed and conclusions drawn.

The results of the analysis show that in the Compilation of Islamic Law it is stated that the implementation of these obligations is a joint obligation between a husband (father) and wife (mother), because husband and wife are complementary parts, namely needing each other and mutual cooperation in living home life. the stairs and raising her kids. Therefore, a mother is considered more appropriate in carrying out the hadhanah because their female instincts are more suitable for caring for and educating children, and their patience in dealing with children's life problems is higher than that of a man. However, in terms of the cost of caring for the child, whatever form it takes, if it is really needed, it is the responsibility of the father that must be fulfilled.

Keywords: custody; child; divorce; positive law; Islamic law
\end{abstract}

\section{Introduction}

Marriage is a contract that legalizes the relationship between a man and a woman to have intercourse as well as an inner and outer bond to live together legally to form an eternal, peaceful and happy family. ${ }^{1}$ In addition, marriage aims to obtain offspring (reproduction / regeneration). ${ }^{2}$

Basically, marriage is a form of long-term engagement, which has legal consequences for husband and wife until the end of the bond. The birth of a child (offspring) automatically creates an inheritance relationship between the parents

\footnotetext{
${ }^{1}$ Ramulyo, Idris. (1996). Hukum Perkawinan Islam: Suatu Analisis dari Undang-Undang No.1 Tahun 1974 dan Kompilasi Hukum Islam, 2nd Printing. Jakarta: Bumi Aksara. p. 1

2 Nasution, Khoiruddin. (2004) Islam tentang Relasi Suami Istri (Hukum Perkawinan 1), cet. ke-1, (Yogyakarta: ACAdeMIA \& TAZAFFA.
} 
and the child, as well as the related family heirs. Because basically the marriage relationship is one of the reasons for an inheritance relationship. ${ }^{3}$

The institution of marriage as a sacred bond between a man and a woman has legal consequences that bind both parties (husband and wife). In terms of the status of the child, Islamic law pays attention to the status of the child, both in terms of the child's status of the biological parents, and inheritance status. to the status of guardianship of children, especially girls when they want to get married. The child's status is related to the marriage performed by the parents. The extent to which the marriage is carried out, whether it is done in a way that has been outlined by Islamic law or not.

Since a husband and wife get a gift in the form of a child as a deposit from Allah Almighty, it means that they have had offspring who will continue their generation and will maintain the quality and quantity of their family. The existence of parents is not only an intermediary for the realization of new beings through birth, but also the responsibility or obligation for them to color and shape the child's personality in the process of growing up to adulthood and able to stand. Therefore, parents must carry out their obligations towards their children because the obligations of these parents in Islamic law are the rights of the child. 4

Children (biological) have a certain position in the family. Parents are obliged to provide a living, education, supervision in worship and character of the child in life until he grows up. ${ }^{5}$ So that in general, matters related to the obligations of parents to children and the rights of children are the obligations to maintain and educate and the obligation to provide for the child.

In Islamic law, the obligations or responsibilities of parents towards children include the responsibility to care for and educate known as hadanah, which is to meet the needs of the child both material, such as providing a living and irda '(breastfeeding) or immaterial in the form of love, maintenance, protection and education for his spiritual development. ${ }^{6}$ In general, hadanah is a form of care for a (small) child to be educated and taken care of all his affairs. ${ }^{7}$

Hadanahis the right of a young child, because he needs supervision, care, executor of his affairs and those who educate him. Jurisprudence experts define hadanah as a form of caring for a child from all kinds of dangers that may befall him, maintaining his physical and spiritual health, maintaining his food and hygiene, seeking education until he is able to stand alone in the face of life as a Muslim. ${ }^{8}$ Hadanah is usually done when there is a divorce between the two parents. ${ }^{9}$

\footnotetext{
${ }^{3}$ Usman, Suparman., \& Somawinata, Yusuf. (2002). Fiqih Mawaris: Hukum Kewarisan Islam. Jakarta: Gaya Media Pratama. p. 28.

${ }^{4}$ Rahmat, Jalaluddin. (1996). Islam Alternatif, Jakarta: Mizan. p. 182

5 Fachruddin, Fuad Mohd. Masalah Anak dalam Hukum Islam., p. 36

${ }^{6}$ Hamid, Zahri. (1997). Pokok-pokok Hukum Perkawinan Islam. Bandung: Bina Cipta. p. 69

${ }^{7}$ Rawwas, Muhammad Qal'ahji. (1999). Ensiklopedi Fiqh Umar Bin Khathab r.a., Translation M. Abdul Mujieb AS, 1st print, Jakarta: PT RajaGrafindo Persada. p. 103

8 Mukhtar, Kamal. (1993). Asas-asas Hukum Islam tentang Perkawinan. cet. ke-3, Jakarta: Bulan Bintang. p. 138

${ }_{9}^{9}$ Syarifuddin, Amir. Hukum Perkawinan Islam., p. 327
} 
Parenting in an Islamic context is more directed at the process of forming a noble character or personality (akhlak karimah). This means that nurturing in Islam does not leave any aspect of the whole spiritual, physical, worldly, intellectual, or instinctive, social individual, and instills a strong system (manhaj) and builds it in a total and balanced manner. ${ }^{10}$

The next problem arises when the provisions regarding child care are enacted in Indonesia which is reflected in Law No. 229 of the Civil Code and KHI Article 156 which still cause various understandings and interpretations so that there seems to be controversy. From this issue, the authors are interested in discussing further the rights of child care between Law no. 229 Civil Code and KHI Article 156. This in-depth discussion of the status of child care provides a little solution to the problems of the people, especially in failed marriages.

Based on the description above, this study aims to determine and analyze the status of child care (hadanah) between Law no. 159 of the Civil Code and Article $156 \mathrm{KHI}$ from the perspective of Islamic law?

\section{Research Methods}

The method of this research approach is normative juridical, the specification of this research is descriptive analytical, the data sources used in this study include secondary data and tertiary data, the data collection method is carried out by literature study and documentation.

\section{Results And Discussion}

\subsection{Childcare}

In Law no. 1 year 1974 provisions regarding the consequences of divorce against children are regulated in Article $41 .^{11}$ The contents of this article are:

a. Either the mother or the father is still obliged to care for and educate the children, solely on the basis of the children's interests, if there is a dispute over the control of the children, the Court gives a decision.

b. The costs of caring for and educating the children are the responsibility of the father, except in the event that the father is unable to carry out this obligation, the Court may determine that the mother is responsible for the costs. And the Court can require the ex-husband to provide living expenses and / or determine an obligation for the ex-wife.

Childcare in Islamic law is called hadanah, while the word Hadanah comes from the word hadana which means to place something between the armpit and navel. A female bird that incubates her egg between her wings and body is called a hadhanah, as is a mother who cradles her child in her arms. Or, more accurately, if the word hadlanah is interpreted as maintenance and education. ${ }^{12}$

The definition of hadhanah in the Islamic encyclopedia is to take care of small or abnormal children who have not or cannot live independently, namely by

${ }^{10}$ Casmini, "Pendidikan Anak: Pola Asuh Orang Tua., p. 263

${ }^{11}$ Article 41 paragraph (1) and (2)

${ }^{12}$ Ayyub, Syaikh Hasan. (2003). Fikih Keluarga . Jakarta : Pustaka al-Kautsar. p. 391. 
fulfilling their daily needs, protecting them from things that are harmful, physical and psychological education and developing their intellectual abilities so that they are able to bear their responsibilities. ${ }^{13}$

The Islamic Law Compilation defines hadlanah as an activity to raise, nurture and educate children to adulthood or be able to stand alone. ${ }^{14}$

Based on the understanding of the hadlanah that has been stated above, an understanding can be drawn that this childcare activity is carried out because of the weaknesses in the child, so that to avoid things that can plunge the child, he needs a care from his parents.

\subsection{Child Care Requirements}

Regarding the problem of taking care of young children when there is a divorce between their parents, in Islamic law and positive law it has been explained that these children are the responsibility and right of a mother to care for them, educate them, so that the child is an adult and can stand on his own. This is in accordance with Article 105 paragraph (1) of the Compilation of Islamic Law which explains that children who are not mumayyiz or not yet 12 years old are the rights of their mothers. ${ }^{15}$ In general, mothers are more often at home, while men have more jobs outside the home. In addition, the characteristics and circumstances of a woman are very necessary for someone who will raise children and educate them. ${ }^{16}$ Therefore, Rasulullah SAW stated that women have more rights to care for children than boys as stated in the hadith.

Then if the mother dies, or is declared incompetent according to sharia, then according to the Islamic Law Compilation, the maintenance of boys and girls is handed over to the sisters in the following priority order:

a. The women in a straight line up from the mother;

b. Father;

c. The women in a straight line up from the father;

d. The sister of the child;

e. The women are blood relatives according to the side line of the mother;

f. The women are blood relatives according to the side line of the father. ${ }^{17}$

However, the right to care for a child can be revoked by a court decision when the child's parent neglects his obligations and the parent misbehaves so that the child can imitate him. ${ }^{18}$

\subsection{Childcare in Law no. 229 Civil Code and Article $156 \mathrm{KHI}$}

Prior to the enactment of the Marriage Law Number 1 of 1974 concerning Marriage, in Indonesia there were various marriage laws that applied to various

\footnotetext{
13 Ensiklopedia Islam, In the Editor, p, 37.

${ }^{14}$ Kompilasi Hukum Islam (KHI) Article 1 paragraph (9).

15 Article 105 paragraph (1)..

16 Mukhtar, Kamal. (1974). Asas-asas Hukum Islam tentang Perkawinan. Jakarta: Bulan Bintang. p.140.

17 Kompilasi Hukum Islam, Article 156.

18 Law No. 1 of 1974 concerning Marriage, Article 49 paragraph (1).
} 
groups of the population from various regions, namely:

a. For indigenous Indonesians who are Muslim, the religious law that has been prescribed in customary law applies.

b. For other Indigenous Indonesians, customary law applies.

c. For Indigenous Indonesians who are Christian, the Huwelijke Ordonantie Christen Indonesiers (S. 1933 Number. 74) applies.

d. For other Eastern Foreigners, and Indonesian Citizens of Chinese descent, the provisions of the Civil Code with minor changes apply.

e. For European people and Indonesian citizens of European descent and their equivalents, the Civil Code applies.

Law No. 229 Civil Code, The Law explains that: After deciding on the divorce, and having heard or legally heard or summoned the parents or blood relatives or a penny of the minors, the District Court will determine which of the two parents will exercise custody of each child, unless both parents are fired or released from parental power, with due observance of previous judges' decisions which may dismiss or release them from parental power.

Article $156 \mathrm{KHI}$, In this article, it is explained that: The consequences of breaking a marriage due to divorce are: a. a child who is not yet mumayyiz has the right to receive hadhanah and his mother, unless the mother has passed away, then his position is replaced by: 1 . women in a straight line up from the mother. 2 . father. 3. women in a straight line up from the father. 4 . the sister of the child. 5. women blood relatives according to the side line of the father. b. children who are mumayyiz have the right to choose to get hadhanah from their father or mother. c. If the holder of hadhanah is unable to guarantee physical and spiritual safety, even though the cost of living and hadhanah has been fulfilled, then at the request of the relative concerned the Religious Court can transfer hadhanah rights to other relatives who have hadhanah rights as well. d. All hadhanah costs and child support are the responsibility of the father according to his abilities, at least until the child is an adult can take care of himself ( 21 years). e. in the event of a dispute regarding the hadhanah and subsistence of the child, the Religious Court gives its decision based on letters (a), (b), and (d). f.In the Civil Code, the background regarding guardianship arrangements in the Civil Code is that the interests of the child who is under the Trusteeship are not harmed or receive adequate guarantees from his guardian, especially regarding self-care and management of his assets. Guardianship according to the Marriage Law includes both the personal and property of the child. This guardianship may occur because the person is incapacitated, the parent is under interdiction (curatele), the parents are divorced and may be because the parent has passed away and if the parents are still able, there is no guardianship.

Child custody is often an issue before or after divorce. In fact, it is not uncommon for ex-husbands and ex-wives to fight for custody of their children. The most extreme is that the struggle for children is carried out with violence, until the parties use the services of thugs, which of course can create new problems if their actions are carried out outside of legal provisions. Not infrequently, if there are parties who have pocketed the ruling of the religious court to care for children, but do not obey and implement it, aka do not properly care for the children entrusted 
to them. If the divorce of husband and wife has reached a level that cannot be revoked, then the problem is minors, namely children who are not yet mature.

Child Protection Law Number 23 of 2002 Protection of Children (Child Protection Law), defines that a child is someone who is not yet 18 (eighteen) years old, including children who are still in the womb. Children in the scope of being part of the object that receive legal consequences for the occurrence of divorce are only legitimate children. This means a child born in or as a result of a legal marriage. Who between husband and wife has the right to care for the child is the wife (mother) as the argument that the mother is more entitled than the father to the hadlonah of the child if there is a dispute about this. This is precisely for the sake of seeing the interests of the child, therefore the child may be handed over to the mother.

\subsection{Responsibilities of Parents to Children}

Since a husband and wife get a gift in the form of a child as a deposit from Allah Almighty, it means that they have had offspring who will continue their generation and will maintain the quality and quantity of their family. The existence of parents is not only an intermediary for the realization of new beings through birth, but also the responsibility or obligation for them to color and shape the child's personality in the process of growing up to adulthood and able to stand. Therefore, parents must carry out their obligations towards their children because the obligations of these parents in Islamic law are the rights of the child. ${ }^{19}$

Children (biological) have a certain position towards the family. Parents are obliged to provide a living, education, supervision in worship and character of the child in life until he grows up. ${ }^{20}$ So that in general, matters relating to the obligations of parents to children and the rights of children are the obligations to maintain and educate and the obligation to provide for the child.

The necessity of providing for a husband is not only when he is still a wife and for the children of his wife, the husband is also obliged to provide for her after the divorce. There are some people who may mistreat their wives and make them miserable after the first divorce and during the 'iddah period. This is not allowed, and she must be provided with a balanced income, according to the husband's standard of living.

Iddah in terms, is the period of waiting for a woman to marry after the divorce from her husband, either divorced or divorced, with the aim of knowing the condition of her womb or to think for her husband.21

Care for the child and the welfare of the mother is the responsibility of a father. Even though the two of them have divorced, the husband is still given an obligation to improve the welfare of his ex-wife and children due to the marriage between the two. Then, if the mother is unable to breastfeed or circumstances

\footnotetext{
${ }^{19}$ Rahmat, Jalaluddin. (1996). Islam Alternatif, Jakarta: Mizan. p. 182

${ }^{20}$ Fachruddin, Fuad Mohd. (1991) Masalah Anak dalam Hukum Islam. Jakarta: CV Pedoman Ilmu Jaya. p. 36

${ }^{21}$ Dahlan, Abdul Aziz. (1996). Ensiklopedi Hukum Islam. Jakarta: Ikhtisar Boru van hove. II: 637.
} 
arise that prevent her from breastfeeding the child, it is also the father's responsibility to leave it to someone else to care for at his own expense. ${ }^{22}$

According to Syafi'i and Hambali, women who care for them are entitled to wages for the care they give, whether they have the status of their own mother or someone else's for the child. Shafi'i emphasized that when the child who is cared for has his own property, then the wages are taken from his property, while if not, the wages are the responsibility of the father or the person who is obliged to provide for the child. ${ }^{23}$

\section{Closing}

From the description above it can be concluded that in the Compilation of Islamic Law it is stated that the implementation of these obligations is a joint obligation between a husband (father) and wife (mother), because husband and wife are complementary parts, namely needing each other and mutual cooperation. in living a domestic life and raising their children. Therefore, mothers feel more appropriate in carrying out the hadhanah because their female instincts are more suitable for caring for and educating children, and their patience in dealing with children's life problems is higher than that of a man. However, in terms of the cost of caring for the child, whatever form it takes, if it is really needed, it is the responsibility of the father that must be fulfilled.

For that suggestions can be made are For parents, as parties who have a role and who are urgent in being responsible for the sustainability of their children's lives, let parents really and truly pay attention to problems related to child care.; Guardianship or custody should be given to parties who have spare time to care for children. Then financially, it is also mature enough to meet the needs of the child, including the cost of education. However, if this is not agreed upon, then the court process is the solution; It is hoped that the community can respect the rights of others related to their obligations so that they do not cause harm to these other people.

\section{Bibliography}

A. Rahman. (2002). Penjelasan Lengkap Hukum-hukum Allah. Jakarta: PT Raja Grafindo Persada.

Ayyub, Syaikh Hasan. (2003). Fikih Keluarga . Jakarta : Pustaka al-Kautsar.

Casmini, "Pendidikan Anak: Pola Asuh Orang Tua

Dahlan, Abdul Aziz. (1996). Ensiklopedi Hukum Islam. Jakarta: Ikhtisar Boru van hove. II.

Fachruddin, Fuad Mohd. (1991) Masalah Anak dalam Hukum Islam. Jakarta: CV Pedoman Ilmu Jaya.

\footnotetext{
${ }^{22}$ A. Rahman. (2002). Penjelasan Lengkap Hukum-hukum Allah. Jakarta: PT Raja Grafindo Persada. p. 270.

${ }^{23}$ Mughniyah. (1994). Fiqh Lima Mazhab. alih bahasa: Afif Muhammad. cet. ke-1 . Jakarta: Basrie Press. hlm.137.
} 
Fachruddin, Fuad Mohd. (1991). Masalah Anak dalam Hukum Islam. Jakarta: Pedoman Ilmu Jaya

Hamid, Zahri. (1997). Pokok-pokok Hukum Perkawinan Islam. Bandung: Bina Cipta.

Mughniyah. (1994). Fiqh Lima Mazhab. alih bahasa: Afif Muhammad. cet. ke-1 . Jakarta: Basrie Press.

Mukhtar, Kamal. (1974). Asas-asas Hukum Islam tentang Perkawinan. Jakarta: Bulan Bintang.

Mukhtar, Kamal. (1993). Asas-asas Hukum Islam tentang Perkawinan. cet. ke-3, Jakarta: Bulan Bintang.

Nasution, Khoiruddin. (2004) Islam tentang Relasi Suami Istri (Hukum Perkawinan 1), cet. ke-1, (Yogyakarta: ACAdeMIA \& TAZAFFA.

Rahmat, Jalaluddin. (1996). Islam Alternatif, Jakarta: Mizan.

Rahmat, Jalaluddin. (1996). Islam Alternatif, Jakarta: Mizan.

Ramulyo, Idris. (1996). Hukum Perkawinan Islam: Suatu Analisis dari UndangUndang No.1 Tahun 1974 dan Kompilasi Hukum Islam, 2nd Printing. Jakarta: Bumi Aksara.

Rawwas, Muhammad Qal'ahji. (1999). Ensiklopedi Fiqh Umar Bin Khathab r.a., Translation M. Abdul Mujieb AS, 1st print, Jakarta: PT RajaGrafindo Persada.

Syarifuddin, Amir. (2006) Hukum Perkawinan Islam. Jakarta: Kencana.

Usman, Suparman., \& Somawinata, Yusuf. (2002). Fiqih Mawaris: Hukum Kewarisan Islam. Jakarta: Gaya Media Pratama. 